\title{
Antitumour Effects of Isocurcumenol Isolated from Curcuma zedoaria Rhizomes on Human and Murine Cancer Cells
}

\author{
S. Lakshmi, ${ }^{1}$ G. Padmaja, ${ }^{2}$ and P. Remani ${ }^{1}$ \\ ${ }^{1}$ Division of Cancer Research, Regional Cancer Centre, Thiruvananthapuram, Kerala 695011, India \\ ${ }^{2}$ Division of Crop Utilisation and Biotechnology, Central Tuber Crops Research Institute, Thiruvananthapuram, Kerala 695011, India
}

Correspondence should be addressed to S. Lakshmi, lakshmi_deependran@yahoo.co.in

Received 28 October 2010; Accepted 5 January 2011

Academic Editor: Armando Rossello

Copyright (C) 2011 S. Lakshmi et al. This is an open access article distributed under the Creative Commons Attribution License, which permits unrestricted use, distribution, and reproduction in any medium, provided the original work is properly cited.

\begin{abstract}
Curcuma zedoaria belonging to the family Zingiberaceae has been used in the traditional system of medicine in India and Southwest Asia in treating many human ailments and is found to possess many biological activities. The rationale of the present study was to isolate, identify, and characterize antitumour principles from the rhizomes of Curcuma zedoaria, to assess its cytotoxic effects on human and murine cancer cells, to determine its apoptosis inducing capacity in cancer cells, and to evaluate its tumour reducing properties in in vivo mice models. Isocurcumenol was characterized as the active compound by spectroscopy and was found to inhibit the proliferation of cancer cells without inducing significant toxicity to the normal cells. Fluorescent staining exhibited the morphological features of apoptosis in the compound-treated cancer cells. In vivo tumour reduction studies revealed that a dose of $35.7 \mathrm{mg} / \mathrm{kg}$ body weight significantly reduced the ascitic tumour in DLA-challenged mice and increased the lifespan with respect to untreated control mice.
\end{abstract}

\section{Introduction}

Plants have been a source of medicine for thousands of years, and phytochemicals continue to play an essential role in medicine [1]. Several of the current chemotherapeutic drugs like vinblastine, methotrexate, taxol, and so forth, were first identified in plants. In developing countries, the practice of medicine still relies heavily on plant and herbal extracts for the treatment of human ailments. Dietary agents consist of a wide variety of biologically active compounds that are ubiquitous in plants, and many of them have been used as traditional medicines [2-4]. Some phytochemicals derived in spices and herbs as well as other plants possess substantial cancer preventive properties [5-10].

Plants of ginger family (Zingiberaceae) have been frequently and widely used as spices and in traditional systems of medicine practiced in many Asian countries, and their medicinal functions have been broadly discussed and accepted in many traditional recipes [11]. The Zingiberaceae plants contain a number of volatile and essential oils including terpenoids, phenylpropanoids, flavonoids, and sesquiterpenes, which has reported antitumour activity [1214]. As plants of Zingiberaceae family are considered safe for human consumption, these species are excellent candidates for development of novel chemotherapeutics [15]. Traditionally, curcuma drugs called "Ukon" and "Gajutsu" in Japanese have been used in oketsu syndromes (caused by the obstruction of blood circulation) in Chinese medicine [16]. Various antineoplastic compounds have also been isolated from curcuma species [17-21].

Curcuma zedoaria, a medicinal tuber plant belonging to this family, is a close relative of Curcuma longa from which the curcumin is isolated. Various parts of Curcuma zedoaria are used in Ayurveda and other folk and tribal system of medicines [22]. Curcuma zedoaria is a constituent of a wide variety of ayurvedic preparations like Dasamularishtam, Valiya Rasnadi Kashayam, and so forth. The rhizome is used for curing stomach diseases, toothache, blood stagnation, leucoderma, tuberculosis, enlargement of spleen, and for promoting menstruation in traditional medicine in Asia [23]. Anti-inflammatory activity $[24,25]$, antifungal activity [26], antiulcer activity $[27,28]$, antimicrobial effect [13, $28,29]$, hepatoprotective activity [30, 31], antiamoebic effect [32], of this plant rhizome have been reported. The Curcuma zedoaria rhizome is termed Ezhu in Chinese and is extensively used in traditional Chinese medicine to treat 
various ovarian and cervical cancers. Curdione isolated from this plant has been found to inhibit prostaglandin E2 production and cyclooxygenase- 2 expression, both of which are implicated in inflammation and carcinogenic process [33].

Some novel compounds like curuminoids have been isolated from Curcuma zedoaria which has inhibitory activity against Ovarian cancer cell lines (OVCAR-3) [34]. Elemene isolated from Curcuma zedoaria rhizome has been found to have substantial antitumour activity against promyelocytic leukemic HL-60 cells [14]. Curcumin and curcumenol are reported to inhibit the growth of S-180 sarcoma cells and mouse cervical U-14 cells [13]. The rhizomes are reported to contain several sesquiterpenoid compounds $[35,36]$. CZ1-III, the polysaccharide fractions from Curcuma zedoaria, was found to decrease the tumor size sarcoma 180 of mouse and prevents chromosomal mutation [37]. Macrophagestimulating activity of Curcuma zedoaria and its possibility of being used as a biological response modifier have been reported [38]. Essential oil isolated from Curcuma wenyujin, a close relative of Curcuma zedoaria, was found to induce apoptosis and inhibit the proliferation of human hepatoma and cervical cancer cells [39]. In the present study, attempts were made to isolate and characterize the active principles from the rhizomes of Curcuma zedoaria collected from Thiruvananthapuram district, Kerala, and to evaluate its cytotoxicity and antiproliferative activity on human lung, leukemic, nasopharyngeal, and murine cancer cell lines.

\section{Experimental}

2.1. Chemicals and Reagents. (3-(4,5-dimethylthiazol-2-yl)2,5 diphenyltetrazolium bromide) (MTT), foetal bovine serum (FBS), acridine orange, ethidium bromide, Sigma-Aldrich, St. Louis, MO, USA; Dulbecco's Modified Eagle's Medium (DMEM), Rosewell Park Memorial Institute (RPMI), Hoechst 33342, Invitrogen; Cyclophosphamide Dabur Pharmaceuticals Ltd. All the chemicals used were of analytical grade.

2.2. Isolation and Purification of the Active Principles. The rhizomes of Curcuma zedoaria were collected from Central Tuber Crops Research Institute, Thiruvananthapuram, authenticated by the taxonomist, and a voucher specimen 41622 (TBGT) has been kept in the herbarium of Tropical Botanical Garden Research Institute, Thiruvananthapuram. As the preliminary studies conducted in our lab showed the potency of the petroleum ether fraction isolated from C. zedoaria, steps were taken to purify and characterize the antitumour principles from this fraction. The shade dried rhizomes were powdered $(900 \mathrm{~g})$ and were extracted with petroleum ether using a soxhlet apparatus for 48 hours. The yield of the extract obtained from C. zedoaria was $20.3 \mathrm{~g}$. The petroleum ether extract isolated was made completely free of the solvent traces and mixed with cold diethyl ether and prewarmed silica. Suction was given to completely evaporate off the solvent. The contents obtained were poured in a Petri plate and kept in a hot air oven set at $50^{\circ} \mathrm{C}$. After mixing it thoroughly, 10 grams of the petroleum ether extract were passed through columns packed with silica gel (100200) mesh size set in Petroleum ether. Elution was done using the solvents $100 \%$ Petroleum ether, different ratios of Petroleum ether: ethyl acetate, ethyl acetate, different ratios of Ethyl acetate: methanol, and 100\% methanol in the order of increasing polarity. Finally the column was washed with methanol alone. The different eluted fractions were collected and concentrated using a rotavapour.

\subsection{Chemical Composition of the Active Petroleum Ether} Fraction of Curcuma zedoaria by GC-MS. The compounds present in the active Petroleum ether fraction were identified by Gas Chromatography Mass Spectrophotometry (GCMS) (GC-MS Shimadzu QP 2010). The specifications were the following: Column DB-5, injection temperature: $200^{\circ} \mathrm{C}$, Interphase temperature: $200^{\circ} \mathrm{C}$, ion source temperature: $200^{\circ} \mathrm{C}$, The column temperatures were programmed from $50^{\circ} \mathrm{C}$ to $280^{\circ} \mathrm{C}$ at the rate of $100^{\circ} \mathrm{C} / \mathrm{min}$.

2.4. Thin Layer Chromatography. After concentrating the samples, thin layer chromatography (TLC) of the different samples collected was done. Samples which gave similar spots on TLC were pooled. Petroleum ether was added to the pooled samples and kept for crystallization.

2.5. Identification of the Active Fractions by Cytotoxicity Assay. The individual pooled fractions were subjected to MTT assay on DLA and A549 cancer cells to determine the active fraction among the various pooled fractions.

2.6. Characterization of the Active Compound. The dried crystals obtained were used for estimating mass spectra (MS) and infrared (IR) spectra. Mass spectrums were recorded on Agilent Technologies 1200 series Mass Spectrometer (Chem station software). IR spectrums were recorded on Perkin-Elmer spectrum 100-FTIR instrument (UK). It can identify unknown materials and can determine the quality or consistency of a sample and the amount of components in a mixture.

2.7. Cell Lines and Culture Conditions. Daltons Lymphoma Ascites (DLAs) cells were maintained in the peritoneal cavity of Balb/c mice (6-8 weeks old). Lung Carcinoma (A549), nasopharyngeal carcinoma (KB), leukemic (K562), Chicken embryo fibroblasts (normal primary cell lines) were maintained in Dulbecco's Modified Eagle's Medium (DMEM) supplemented with 10\% Foetal Bovine Serum (FBS) in a $5 \% \mathrm{CO}_{2}$ incubator at $37^{\circ} \mathrm{C}$ supplemented with penicillin $(100 \mathrm{U} / \mathrm{mL})$ and streptomycin $(100 \mu \mathrm{g} / \mathrm{mL})$.

2.8. Isolation of Lymphocytes from Whole Blood. Three $\mathrm{ml}$ of blood were taken from normal healthy individuals and collected in heparinised test tube. Five $\mathrm{ml}$ of Phosphate Buffered Saline (PBS) were added and mixed well. Two ml of ficoll hypaque solution were taken and carefully layered blood PBS mixture on to the ficoll hypaque solution. It was centrifuged at $2000 \mathrm{rpm}$ for 30 minutes. The opaque interface 


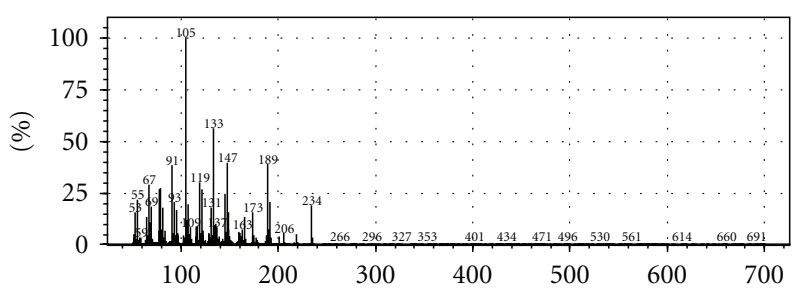

(a) Isocurcumenol $(25.24 \%)$

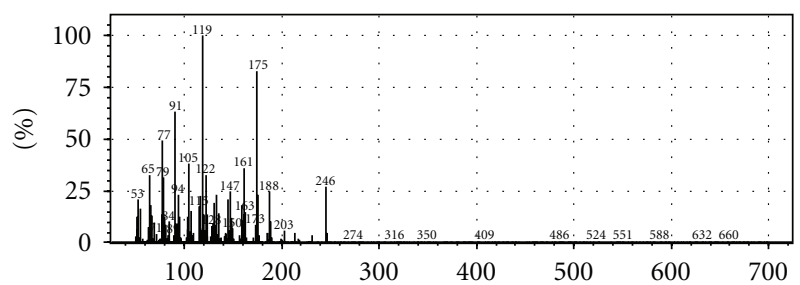

(c) Elemene $(3.75 \%)$

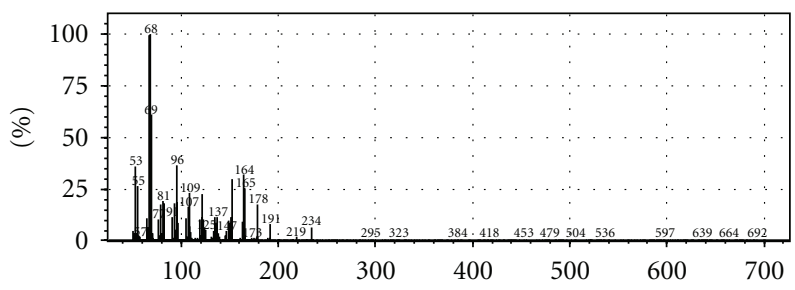

(b) Methyl sterolate $(24.94 \%)$

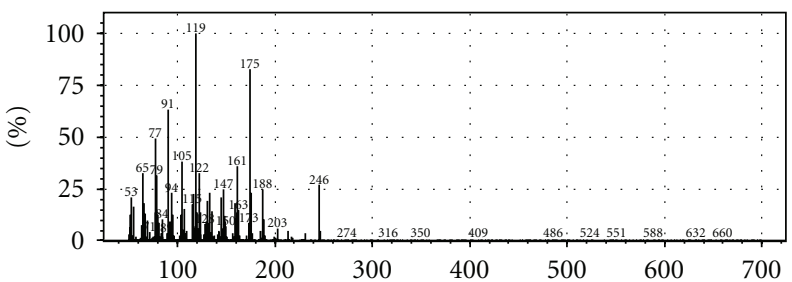

(d) Isolongifolene $(9.31 \%)$

FIgure 1: Mass spectra of the four major compounds present in Petroleum ether fraction of Curcuma zedoaria. (a) Isocurcumenol. (b) Methyl sterolate. (c) Elemene. (d) Isolongifolene.

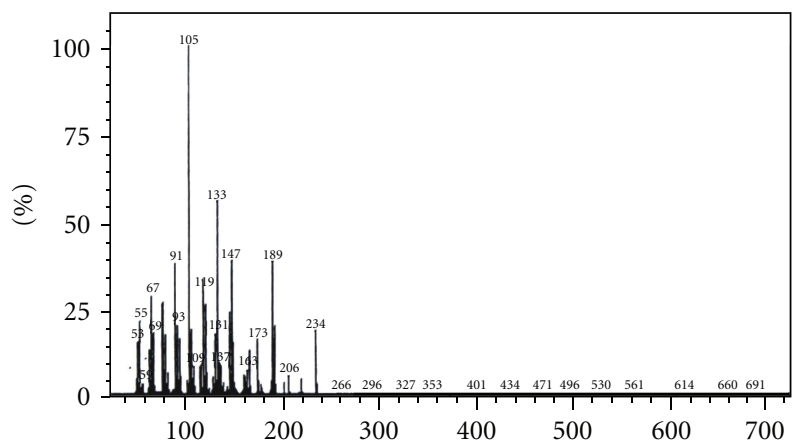

FIGURE 2: MS Spectrum of the active compound isolated from Curcuma zedoaria.

containing mononuclear cells was collected, mixed with PBS, and centrifuged at $1500 \mathrm{rpm}$ for 10 minutes, and supernatant was discarded. The centrifugation was repeated thrice, and the lymphocyte pellet was resuspended in PBS.

2.9. Detection of Cell Viability by MTT Assay. The active compound was dissolved in Dimethyl Sulfoxide (DMSO) and used for MTT assay. Briefly $5 \times 10^{3}$ cells were cultured and incubated for 24, 48, and 72 hours. At the end of incubation period, MTT was added to all the wells and incubated in dark for 2 hours at $37^{\circ} \mathrm{C}$. Then lysis solution (20\% Sodium Dodecyl Sulphate (SDS) in 50\% dimethyl formamide (DMF)) was added and further incubated for 4 hours in dark. After the incubation, the optical density was assessed at $570 \mathrm{~nm}$ using a multiwell plate reader [40]. 5-Fluorouracil was used as the positive control for DLA and A549 cells and doxorubicin for KB and K562 cells. The Inhibitory concentration required for $50 \%$ cytotoxicity $\left(\mathrm{IC}_{50}\right)$ value was analysed using Easyplot software.

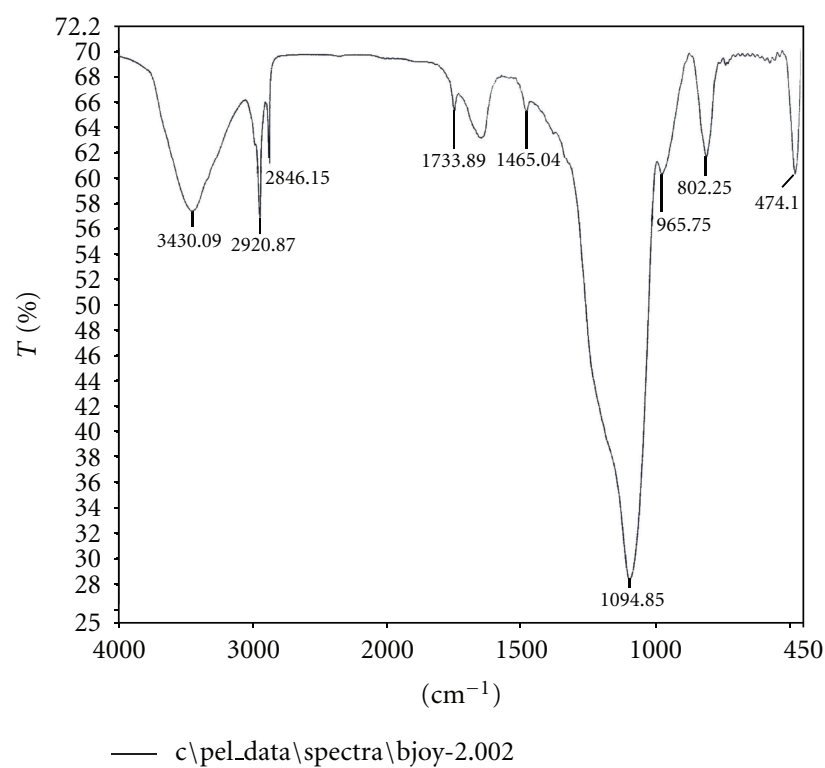

FIgURE 3: IR Spectrum of the active compound isolated from Curcuma zedoaria.

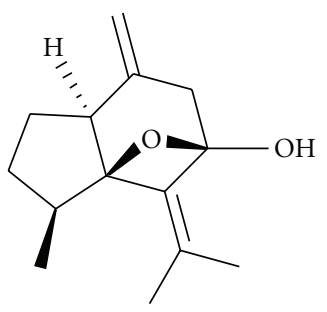

Figure 4: Structure of isocurcumenol purified from Curcuma zedoaria. 


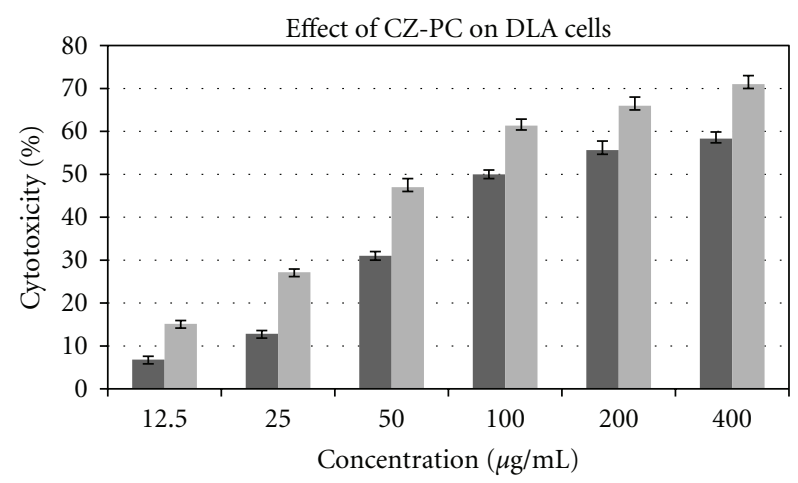

$24 \mathrm{~h}$

- $48 \mathrm{~h}$

(a) DLA cells

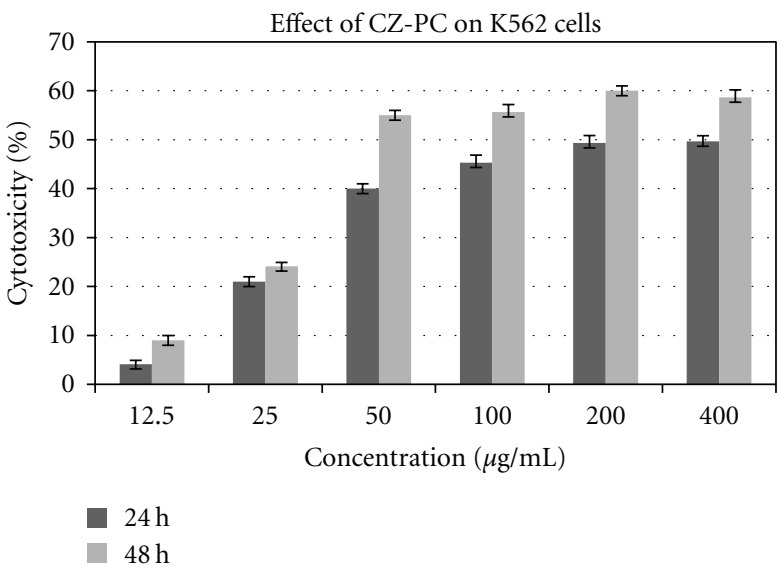

(c) K 562 cells

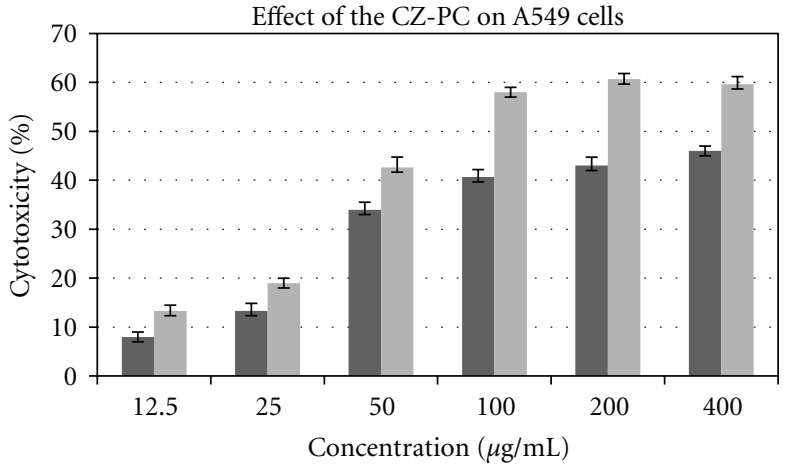

$24 \mathrm{~h}$

$48 \mathrm{~h}$

(b) A 549 cells

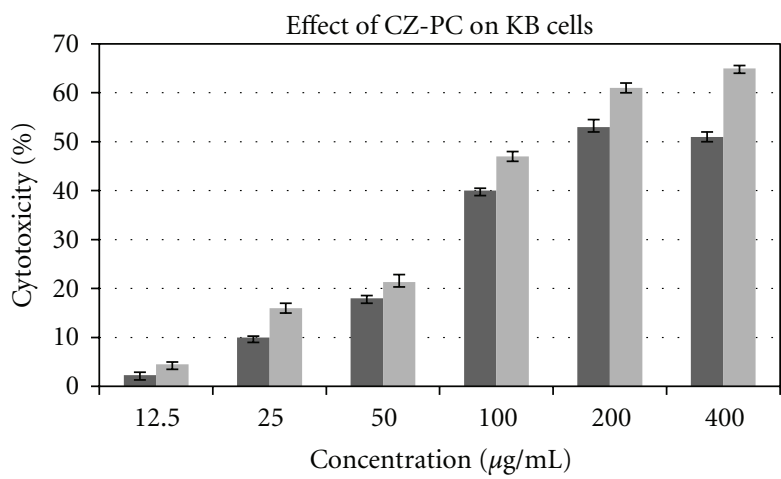

$24 \mathrm{~h}$

$48 \mathrm{~h}$

(d) KB cells

FiguRE 5: Comparison of the \% of cytotoxicity between the cancer cells after 24 and 48 hours of incubation with isocurcumenol (CZ-PC) Curcuma zedoaria pure compound. (a) DLA, (b) A549, (c) K 562, and (d) KB cells.

2.10. Analysis of Apoptotic Features by Acridine OrangeEthidium Bromide and Hoechst Staining. The morphological features of apoptosis induced by the active compound were evaluated by Acridine Orange-Ethidium Bromide dual $(\mathrm{AO} / \mathrm{EtBr})$ staining [41] and Hoechst staining [42]. Briefly, cells were seeded in a 96-well plate at a density of $5 \times 10^{5}$ cells and then treated with different concentrations of the compound for 48 hours. After washing once with phosphate buffered saline (PBS), the cells were stained with $100 \mu \mathrm{L}$ of a mixture $(1: 1)$ of acridine orange-ethidium bromide $(4 \mu \mathrm{g} / \mathrm{mL})$ solutions. The cells were immediately washed with PBS and observed under fluorescence microscopy at 450$490 \mathrm{~nm}$. The number of cells manifesting morphological features of apoptosis such as nuclear fragmentation and chromatin condensation were evaluated.

For Hoechst staining, the cells were seeded in a 96well plate at a density of $5 \times 10^{5}$ cells and then treated with different concentrations of the compound for 48 hours. After washing once with PBS, the cells were stained with $100 \mu \mathrm{L}$ of Hoechst $33342(10 \mathrm{mg} / \mathrm{mL}$ stock $)$ and incubated at room temperature for 5 minutes. Stained cells were imaged by fluorescence microscopy at $350-460 \mathrm{~nm}$. The number of cells manifesting chromatin condensation was counted as a function of total number of cells present in the field.

2.11. Acute and Subacute Toxicity Studies in Mice Models. Acute toxicity studies were carried out in Balb/C mice (28$30 \mathrm{~g}$ ) (6 animals per group) by a single intraperitoneal injection of different concentrations of the active purified fraction isolated from Curcuma zedoaria (CZ-PF). The $\mathrm{LD}_{50}$ value (lethal dose for $50 \%$ animals to be killed) was assessed and calculated. Subacute toxicity studies were done by intraperitoneal injection of different sublethal doses of $\mathrm{LD}_{50}$ value once a day for 14 days continuously. Animals treated with normal saline were taken as negative control and those treated with the standard drug, cyclophosphamide (CYP), were taken as positive control. After 14 days, the animals were sacrificed, and the blood was collected to estimate various liver and kidney function tests such as (Serum Glutamate Ortho-Transferase (SGOT), Serum Glutamine Pyruvate Transaminase (SGPT), Alkaline Phosphatase (ALKP), creatinine, and urea) to assess any toxicity induced by the active fraction. 


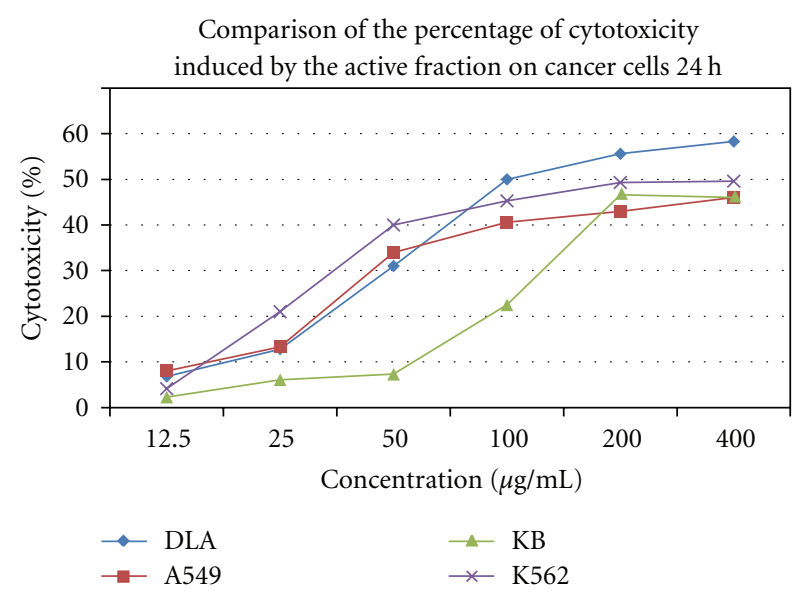

(a) 24 hours

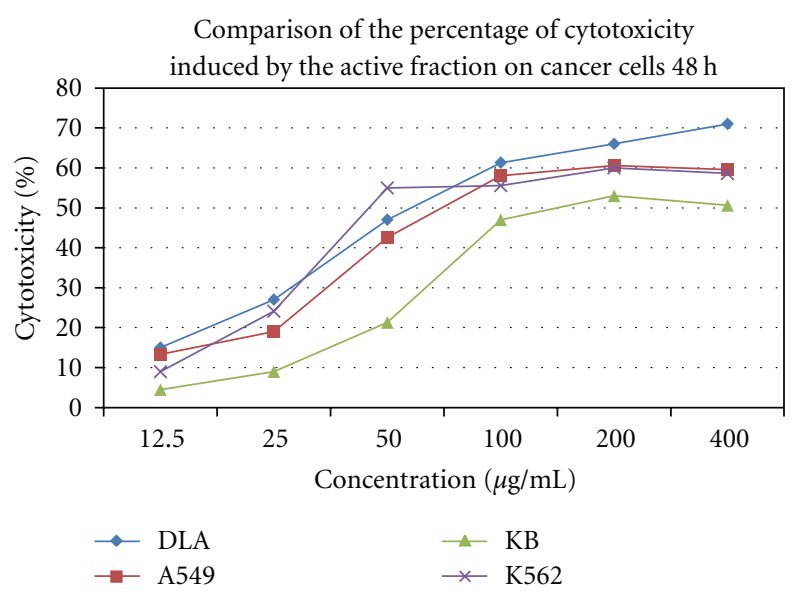

(b) 48 hours

FIgURE 6: Comparison of the \% of cytotoxicity of DLA, A549, KB, and K562 cells after treatment with isocurcumenol for 24 (a) and 48 (b) hours.

2.12. Ascitic Tumour Reduction Studies in Mice Models. $\mathrm{Balb} / \mathrm{c}$ mice (28-30 g) (6 animals per group) were treated with the active fraction alternatively for 21 days one day postDLA ascitic tumour transplantation. After the treatment period, the ascitic fluid was aspirated and calculated using the formula $V 3=(V 1+V 2)-V 2$, where $V 3$ is the total ascetic fluid volume, $V 1$ is the volume of the ascetic fluid obtained from the peritoneum, and $V 2$ is the volume of the added saline [43]. Increment in lifespan (ILS) was assessed according to the formula \%ILS $=(T-C) / C \times 100$, where $T$ represents median survival time of the treated animals and $C$ represents the median survival time of the control group.

2.13. Statistical Analysis. All the in vitro experiments were done in triplicates and for the in vivo experiments, six animals per group were used. Results are expressed as mean \pm standard deviation. Statistical analysis was done by means of one-way Anova followed by Turkey-Kramer multiple comparison test using Graphpad Insta software. $P$ value $<.05$ was considered statistically significant.

\section{Results}

3.1. GC-MS Analysis of the Active Fraction. The phytoconstituents present in the active Petroleum ether extract of Curcuma zedoaria are given in Table 1. The GC-MS analysis revealed that isocurcumenol (25.24\%), methyl sterolate $(24.94 \%)$, isolongifolene (9\%), and elemene (3\%) are the major compounds present in the Petroleum ether fraction. The mass spectra of the compounds are given in Figure 1.

\subsection{Cytotoxicity of the Active Fractions Isolated from Curcuma} zedoaria. The cell viability assay by MTT revealed that $60: 40$ Petroleum ether: ethyl acetate fraction is the active fraction with antiproliferative effects against DLA and A549 cancer cells when treated for 24 and 48 hours. The $\mathrm{IC}_{50}$ values are given in Table 2 .

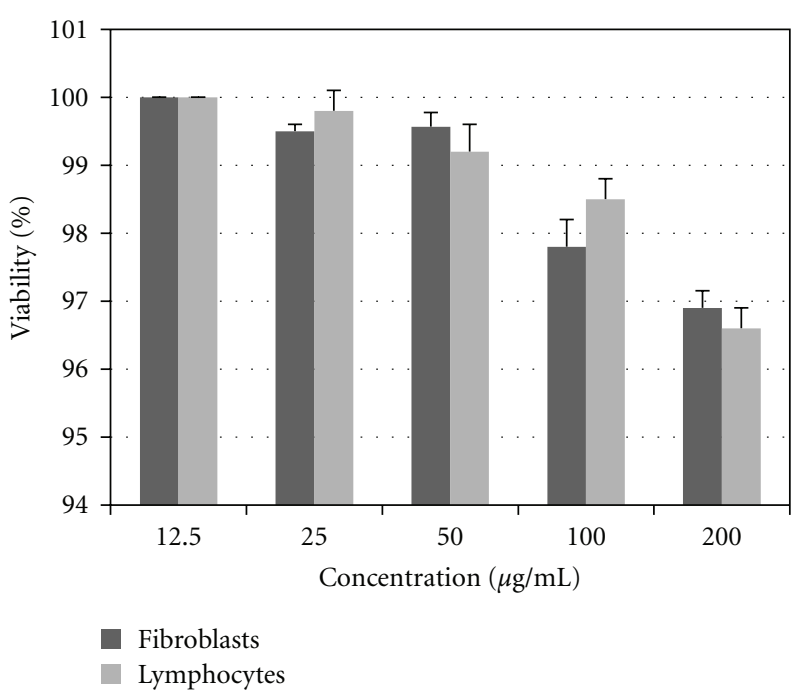

FIGURE 7: Percentage viability after treatment with isocurcumenol on normal lymphocytes and chicken embryo fibroblast cells -72 hours.

3.3. MS Spectral Data of the Active Compound Isolated from Curcuma zedoaria. MS $(\mathrm{m} / \mathrm{z})$, that is, mass/charge ratio is $51,55,67,69,91,93,105,109,119,131,133,137,147163$, $173,189,206,234$. The mass fragmentation pattern suggests the molecular weight of the active compound isolated from Curcuma zedoaria to be 234 (see Figure 2).

3.4. IR Spectral Data of the Active Compound Isolated from Curcuma zedoaria. IR $\left(\mathrm{cm}^{-1}\right)-474(\mathrm{w}), 802.25(\mathrm{w}), 1094.85$ (s), $1465(\mathrm{w}), 1733.89(\mathrm{w}), 2846(\mathrm{w}), 2920(\mathrm{w}), 3430(\mathrm{~b})$ (see Figure 3).

\subsection{Structural Configuration for the Active Compound Isolated} from Curcuma zedoaria from the Spectral Data. From the Petroleum ether: ethyl acetate $(60: 40)$ of C. zedoaria, a pure 


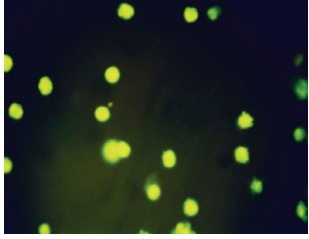

(a) Untreated DLA cells

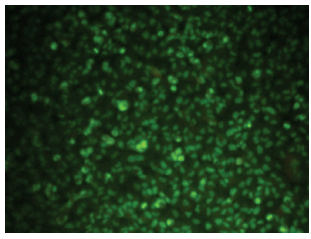

(e) Untreated A 549 cells

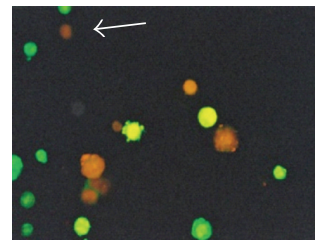

(b) Treated DLA cells $(50 \mu \mathrm{g} / \mathrm{ml})$

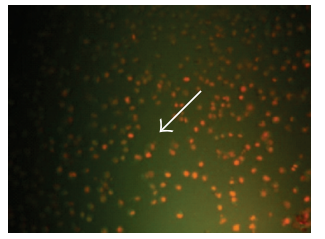

(f) Treated A 549 cells $(50 \mu \mathrm{g} / \mathrm{ml})$

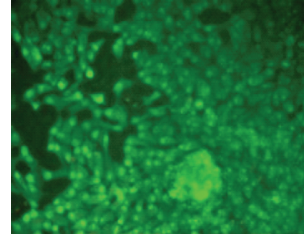

(c) Untreated KB cells

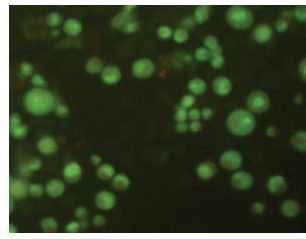

(g) Untreated K562 cells

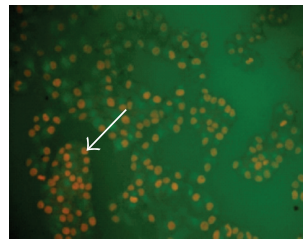

(d) Treated KB cells $(100 \mu \mathrm{g} / \mathrm{ml})$

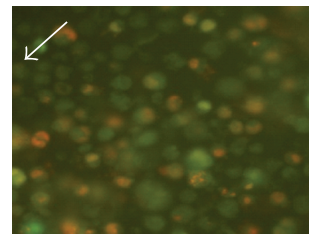

(h) Treated K562 cells $(50 \mu \mathrm{g} / \mathrm{ml})$

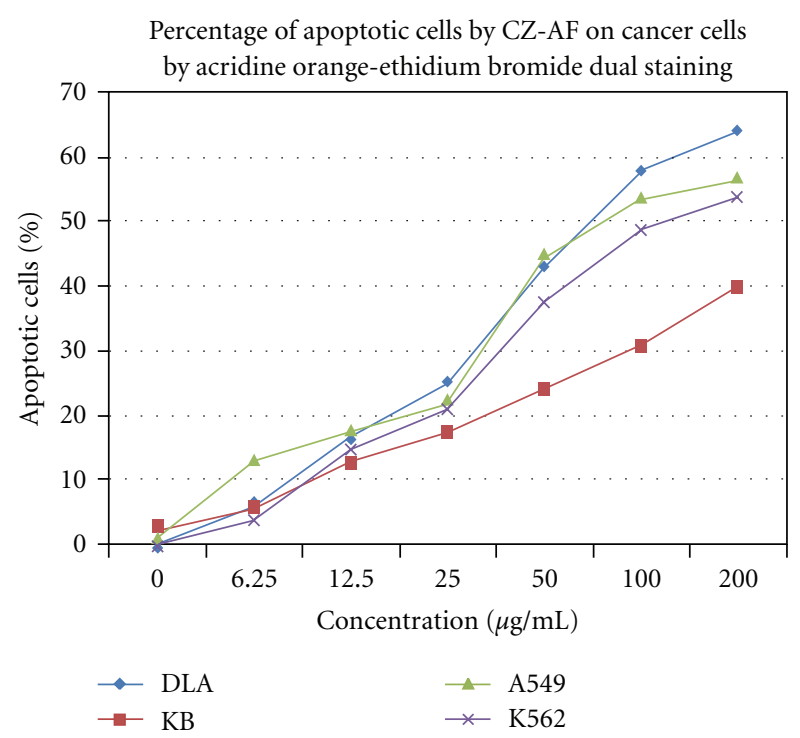

(i) Graph showing the \% of apoptotic cells induced by the activecompound by $\mathrm{AO} / \mathrm{EtBr}$ staining on cancer cell lines $(n=6)$

Figure 8: AO/Et Br staining in DLA cells treated with isocurcumenol (a and b). Untreated and $50 \mu \mathrm{g} / \mathrm{mL}$ treated DLA cells (c and d). Untreated and $100 \mu \mathrm{g} / \mathrm{mL}$ treated $\mathrm{KB}$ cells (e and f). Untreated and $50 \mu \mathrm{g} / \mathrm{mL}$ treated A 549 cells (g and h). Untreated and $50 \mu \mathrm{g} / \mathrm{mL}$ treated K-562 cells. (i) Graph showing the \% of apoptotic cells induced by treatment with isocurcumenol by AO/EtBr staining on cancer cell lines. ( $\uparrow$ ) shows the apoptotic cells.

yellow coloured semisolid oil like compound was isolated. The melting point of the compound isolated was estimated to be $144^{\circ} \mathrm{C}$ experimentally. The active compound crystallized was assigned as isocurcumenol. The structure was confirmed by comparing the spectral values, molecular mass, and the melting point with those reported in the literature [58]. The yield of isocurcumenol isolated from 10 grams of the Petroleum ether extract was 30.7 milligrams. The fraction containing the pure compound isolated from $C$. zedoaria was developed in 50:50 Petroleum ether: Ethyl acetate and developed by spraying using $10 \%$ sulphuric acid in methanol. Phytochemical analysis revealed that the pure compound isolated was of sesquiterpenoid class (see Figure 4).
3.6. Inhibition of Cancer Cell Proliferation by Isocurcumenol. The cell viability assay revealed the potent cytotoxic activity of CZ-PC (Curcuma zedoaria Purified compound), isocurcumenol on various cancer cells (Figures 5(a), 5(b), 5(c), and $5(\mathrm{~d}))$. There was a concentration and time-dependent increase in the percentage of cytotoxicity in DLA, A549, K562 and KB cells. All values obtained were highly significant compared to the untreated control cells $(P<.001) .20 \mu \mathrm{g} / \mathrm{mL}$ of 5 -fluorouracil inhibited $83 \%$ and $71 \%$ of cell proliferation in A549 and DLA cells, respectively, whereas $10 \mu \mathrm{g} / \mathrm{mL}$ of Doxorubicin inhibited $59 \%$ and $78 \%$ of cell proliferation in $\mathrm{K} 562$, and KB cells, respectively. The comparisons between the percentage of cytotoxicity induced by isocurcumenol (CZ-PC) in the different cancer cell lines are given as 


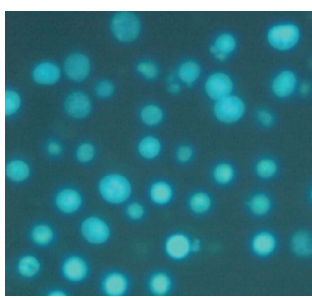

(a) Control DLA cells

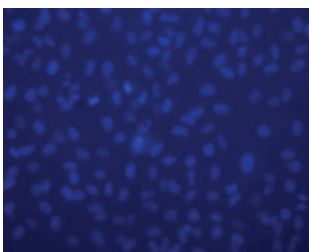

(e) Control KB cells

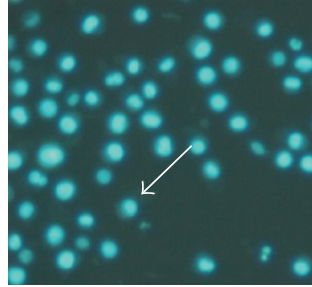

(b) Treated DLA ( $50 \mu \mathrm{g} / \mathrm{ml})$

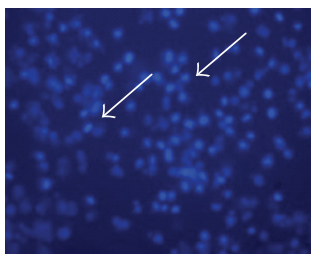

(f) Treated KB cells $(100 \mu \mathrm{g} / \mathrm{ml})$

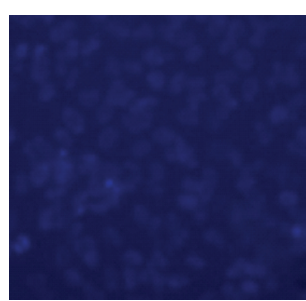

(c) Control A549 cells

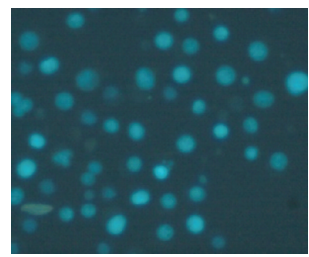

(g) Control K562 cells

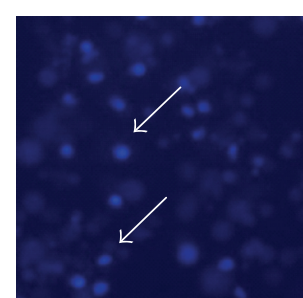

(d) Treated A 549 cells $(50 \mu \mathrm{g} / \mathrm{ml})$

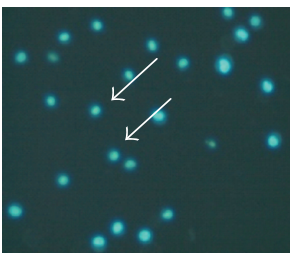

(h) Treated K562 cells $(50 \mu \mathrm{g} / \mathrm{ml})$

Percentage of apoptotic cells induced by CZ-AF on cancer cells by Hoechst staining

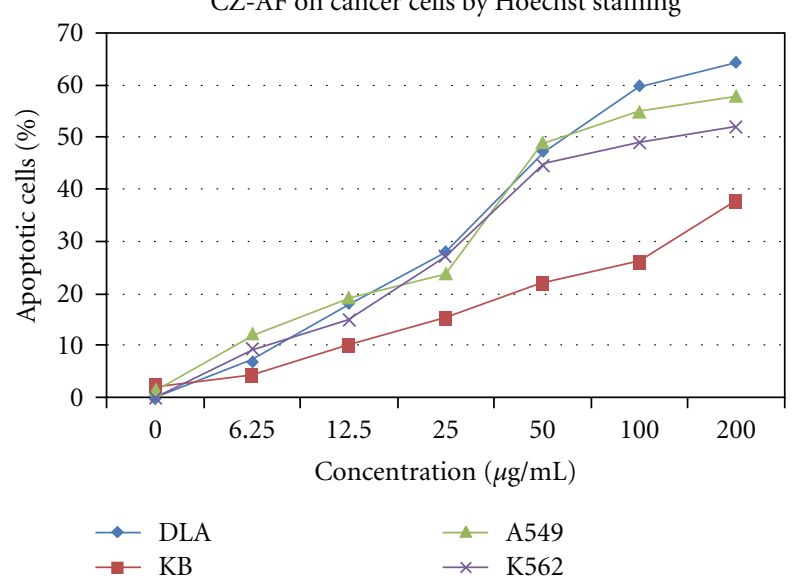

(i) Graph showing the \% of apoptotic cells induced Isocurcumenol treatment by Hoechst staining on cancer cell lines

FIGURE 9: Hoechst staining in DLA cells treated with isocurcumenol (a and b). Untreated and $50 \mu \mathrm{g} / \mathrm{ml}$ treated DLA cells (c and d). Untreated and $100 \mu \mathrm{g} / \mathrm{ml}$ treated $\mathrm{KB}$ cells (e and f). Untreated and $50 \mu \mathrm{g} / \mathrm{ml}$ treated A 549 cells ( $\mathrm{g}$ and $\mathrm{h}$ ). Untreated and $50 \mu \mathrm{g} / \mathrm{ml}$ treated $\mathrm{K} 562 \mathrm{cells}$. (i) Graph showing the \% of apoptotic cells induced by the treatment with isocurcumenol by Hoechst staining on cancer cell lines. $(\uparrow)$ shows the apoptotic cells with chromatin condensation.

Figures 6(a) and 6(b). DLA, A549, and K562 cells were more sensitive to $\mathrm{CZ}-\mathrm{PF}$ than $\mathrm{KB}$ cells. The $\mathrm{IC}_{50}$ values were also determined after 24 and 48 hours of treatment (Table 3). On the contrary, isocurcumenol did not exhibit any significant toxicity on normal chicken embryo fibroblast cells and lymphocytes (Figure 7).

3.7. Induction of Apoptosis by CZ-PF. Dual staining by acridine orange ethidium bromide revealed the characteristic features of apoptosis like chromatin condensation, nuclear fragmentation, and membrane blebbing after 48 hours of treatment with CZ-PF in DLA, A 549, K562, and KB cells (Figure 8). Hoechst staining revealed a greater intensity of blue colour in all the treated cells compared to control cells, which is due to the condensed chromatin, the characteristic feature of apoptosis (Figure 9). There was a concentrationdependent increase in the percentage of apoptotic cells after
48 hours of incubation. There was a significant increase $(P<$ .001 ) in the percentage of apoptotic cells in the DLA, A 549, $\mathrm{K} 562$, and $\mathrm{KB}$ cells at concentrations of $25,50,100$, and $200 \mu \mathrm{g} / \mathrm{mL}$.

3.8. Toxicity Profile in Mice Models. From the acute toxicity studies, it was found that a dose of $500 \mathrm{mg} / \mathrm{kg}$ bw of CZ$\mathrm{PF}$ is the $\mathrm{LD}_{50}$ value. Taking $\mathrm{LD}_{50}$ values as the reference value, $1 / 8$ th, $1 / 10$ th, $1 / 12$ th, and $1 / 14$ th of $\mathrm{LD}_{50}$ values were employed for the further subacute toxicity studies (Figure 10). The results suggested that the purified fraction in low doses manifested no toxic symptoms while very high doses marked toxic as well as depressant activities. Usually the liver and kidney enzymes tend to deviate from their normal range to higher values upon toxicity. Treatment of CZPF (1/12th and 1/14th) of $\mathrm{LD}_{50}$ values, that is, 41.6 and $35.7 \mathrm{mg} / \mathrm{kg}$ bw, did not alter significantly the levels 


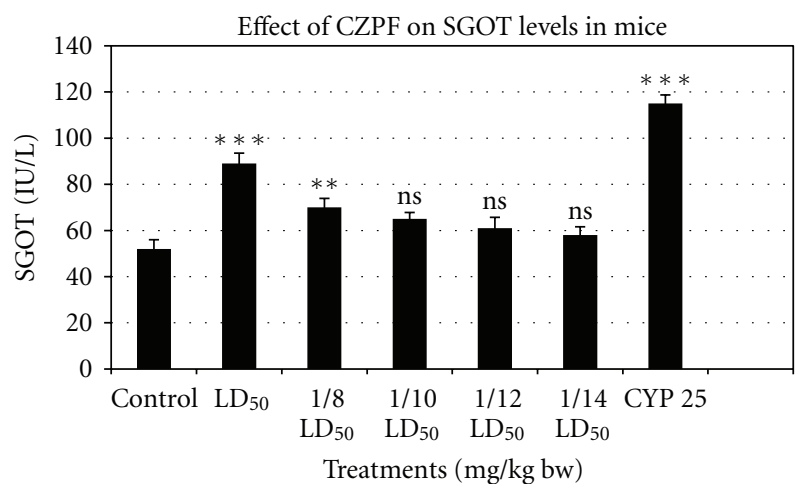

(a)

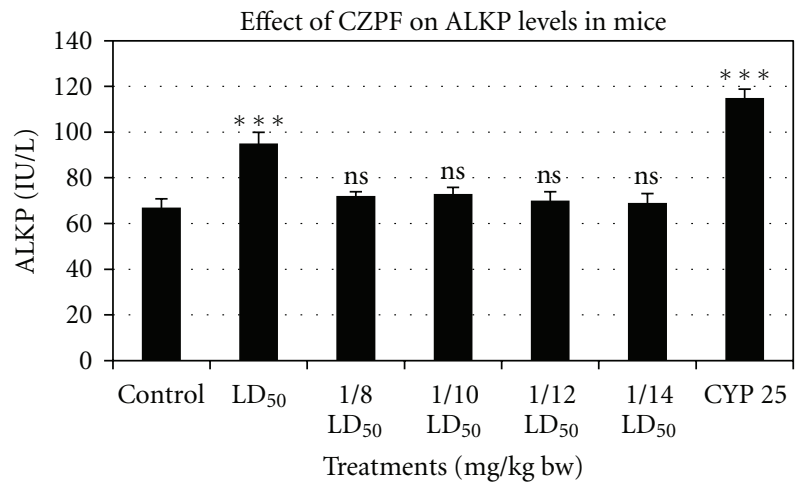

(c)

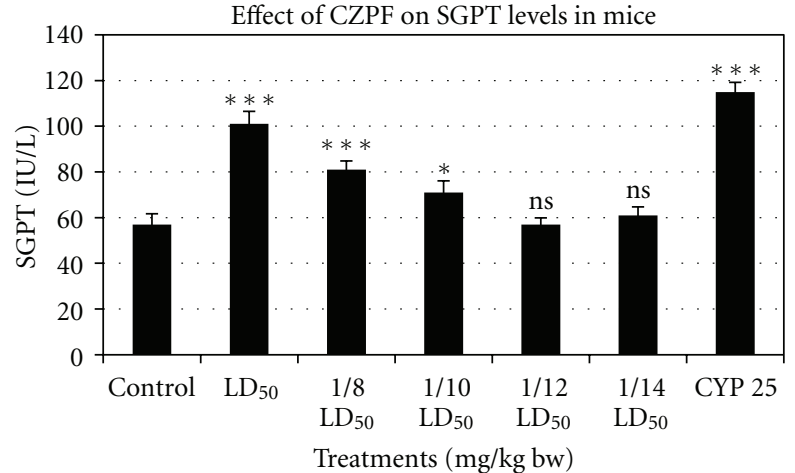

(b)

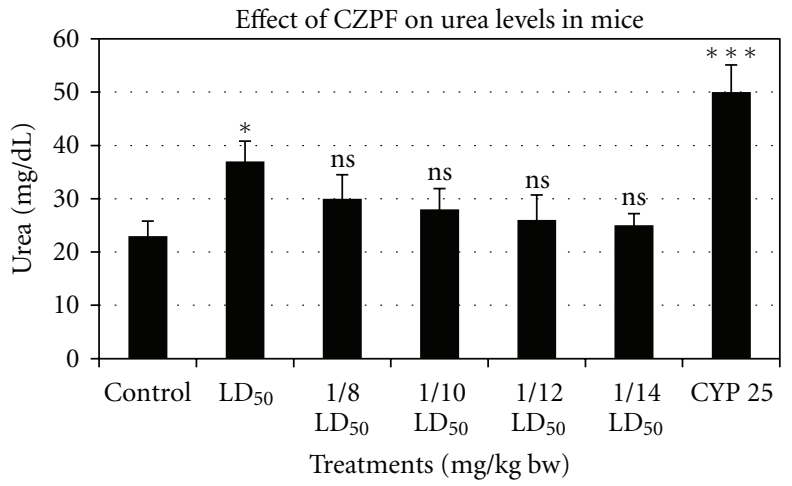

(d)

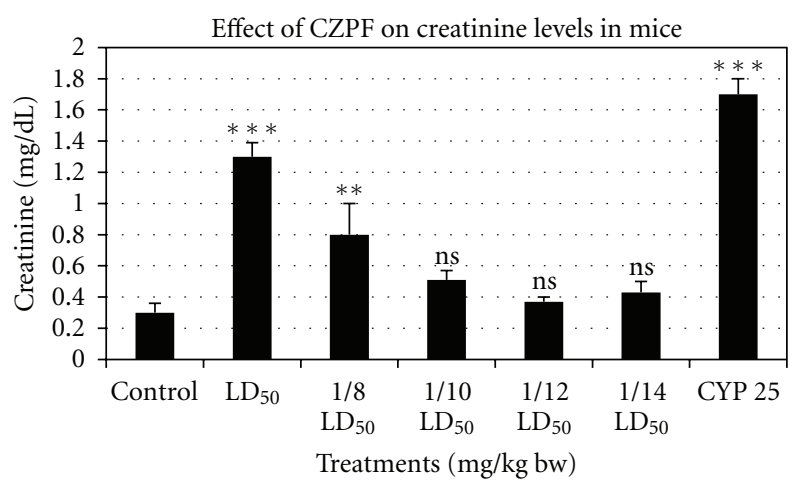

(e)

FIGURE 10: Graphs showing the relative toxicity of different concentrations of CZ-PF and cyclophosphamide on biochemical parameters in animal models. (a) SGOT. (b) SGPT. (c) ALKP. (d) Creatinine. (e) Urea $\left({ }^{*} P<.05,{ }^{* *} P<.01,{ }^{* * *} P<.001,{ }^{\text {ns }} P>.05\right)$.

of SGOT, SGPT, and ALKP levels (liver enzymes) (Figures $10(\mathrm{a}), 10(\mathrm{~b})$, and $10(\mathrm{c}))$ as well as those of creatinine and urea (kidney enzymes) (Figures 10(d) and 10(e)) $(P>.05)$. However animals treated with $\mathrm{LD}_{50}$ doses of CZPF, that is, $500 \mathrm{mg} / \mathrm{kg}$ bw exhibited significant toxicity on the liver and kidney enzyme levels $(P<.001)$, but lower than that of the animals treated with cyclophosphamide. Animals treated with $1 / 8$ th of $\mathrm{LD}_{50}$ values of CZPF, that is, $62.5 \mathrm{mg} / \mathrm{kg} \mathrm{bw}$, exhibited marginal toxicity on SGOT and ALKP levels and significant toxicity on SGPT levels. The same dose of CZPF induced no significant toxicity on urea levels, whereas the same dose induced marginal toxicity in the creatinine levels. These results emphasize the nontoxicity of the purified fractions of CZPF at concentrations of (1/12th and 1/14th) of $\mathrm{LD}_{50}$ values, 41.6 and $35.7 \mathrm{mg} / \mathrm{kg}$ bw, respectively.

\subsection{Ascitic Tumour Reduction in Mice Challenged with DLA} Cells. 6 groups of animals with specific treatment schedule were assigned. Treatment with $1 / 12$ th and 1/14th doses of $\mathrm{LD}_{50}$ values of $\mathrm{CZPF}$ showed that the tumour volume regressed in size from $9.13 \pm 2.1$ in control to $5.3 \pm 1.7$ and $4.8 \pm 1.8$, respectively, and subsequently increased the lifespan of mice to $38 \%$ and $42.8 \%$, respectively. These results revealed that the optimum dose for the maximum antitumour activity of CZPF was $35.7 \mathrm{mg} / \mathrm{kg}$ bw, that is, $1 / 14$ th of $\mathrm{LD}_{50}$ value. In corresponding animals treated with 
TABLE 1: GC-MS profile of the Petroleum ether fraction of Curcuma zedoaria shows the major phytoconstituents and their percentage.

\begin{tabular}{|c|c|c|c|}
\hline Sl No: & Compound & $\begin{array}{l}\text { Retention time } \\
\quad \text { (minutes) }\end{array}$ & $\begin{array}{l}\text { Percentage } \\
(\%)\end{array}$ \\
\hline 1 & Eucalyptol & 9.786 & 2.04 \\
\hline 2 & Camphor & 12.44 & 1.58 \\
\hline 3 & Beta-selinene & 21.008 & 1.03 \\
\hline 4 & Azulene & 21.225 & 0.87 \\
\hline 5 & $\begin{array}{l}\text { 4,5,6,6A-tetrahydro } 2 \\
{[1 \mathrm{H}] \text { pentalenone }}\end{array}$ & 23.752 & 14.49 \\
\hline 6 & Germacrone & 25.783 & 1.87 \\
\hline 7 & Isocurcumenol & 26.623 & 25.24 \\
\hline 8 & $\begin{array}{l}\text { 9-octadecynoic acid } \\
\text { methyl ester }\end{array}$ & 26.948 & 1.36 \\
\hline 9 & Dihydro neoclovene & 27.018 & 3.48 \\
\hline 10 & Methyl sterolate & 27.738 & 24.94 \\
\hline 11 & Isovelleral & 27.886 & 5.92 \\
\hline 12 & Eremanthron & 28.127 & 2.89 \\
\hline 13 & Elemene & 28.883 & 3.75 \\
\hline 14 & Octahydroanthracene & 31.650 & 1.25 \\
\hline 15 & Isolongifolene & 31.961 & 9.31 \\
\hline
\end{tabular}

TABle 2: Cytotoxicity of the active fractions isolated from Curcuma zedoaria.

\begin{tabular}{lcc}
\hline \multirow{2}{*}{ Cell lines } & $60: 40 \mathrm{PE}:$ EA CZ fraction $\mathrm{IC}_{50}$ values $(\mu \mathrm{g} / \mathrm{mL})$ \\
& $24 \mathrm{~h}$ & $48 \mathrm{~h}$ \\
\hline DLA & $95.5 \pm 1.7$ & $77.2 \pm 3.1$ \\
A549 & $>400$ & $73.2 \pm 2.5$ \\
\hline
\end{tabular}

TABLE 3: IC $_{50}$ values on different cancer cells induced by treatment with CZ-PC (Isocurcumenol).

\begin{tabular}{|c|c|c|}
\hline \multirow{2}{*}{ Cells } & \multicolumn{2}{|c|}{$\mathrm{IC}_{50}$ value $(\mu \mathrm{g} / \mathrm{mL})(\mathrm{CZ}-\mathrm{PC})$} \\
\hline & $24 \mathrm{~h}$ & $48 \mathrm{~h}$ \\
\hline DLA & $99.1 \pm 1.7$ & $75.3 \pm 1.5$ \\
\hline A549 & $>400$ & $75.7 \pm 1.3$ \\
\hline $\mathrm{KB}$ & $178.2 \pm 0.4$ & $142.2 \pm 1.1$ \\
\hline K562 & $>400$ & $45.83 \pm 2.4$ \\
\hline
\end{tabular}

CYP, the tumour volume regression was observed to be a value very near to that of those treated with $35.7 \mathrm{mg} / \mathrm{kg}$ bw of CZPF. Table 4 illustrates the effects of the i.p administration of different doses of CZPF and cyclophosphamide on the lifespan of DLA bearing mice. Figures 11 and 12 illustrate the effects of the i.p administration of different doses of CZPF in comparison with CYP on the life span and tumour volumes in DLA-challenged mice.

\section{Discussion}

The Zingiberaceae plants are well reported to possess many bioactive compounds and are known to induce apoptosis in cancer cells. 6-gingerol isolated from Zingiber offinalis

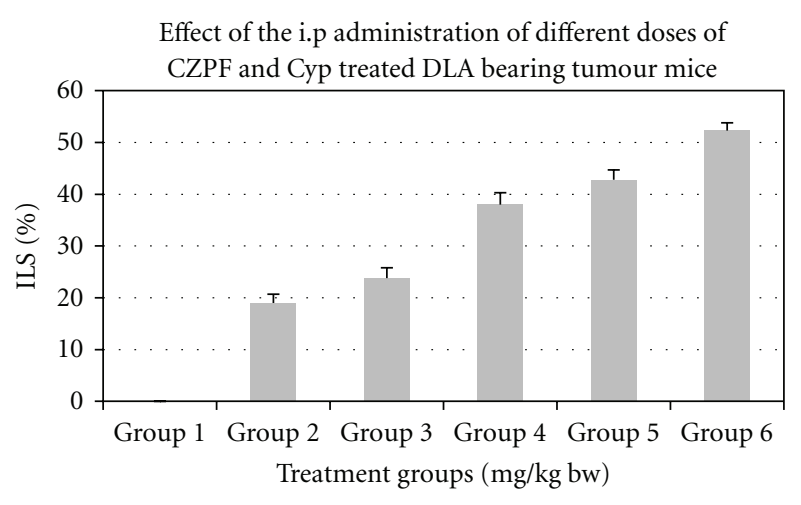

CZPF

FIGURE 11: Effect of the i.p administration of different doses of CZPF and cyclophosphamide on the life span of DLA bearing mice.

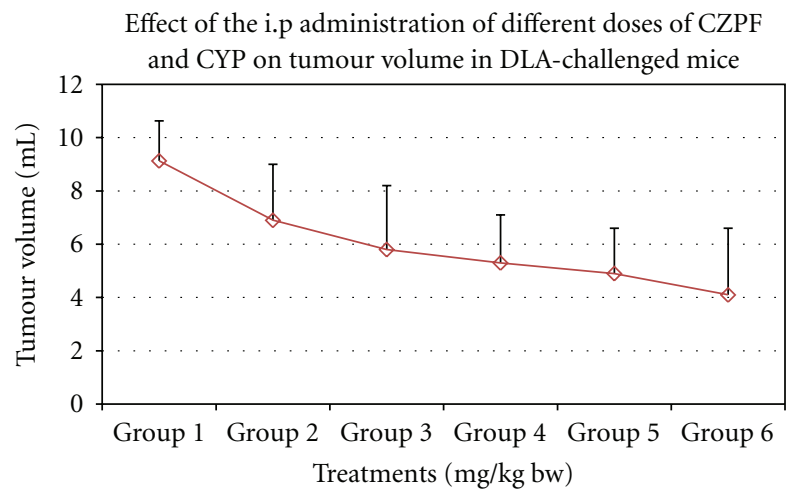

FIGURE 12: Effect of the i.p administration of different doses of CZPF and CYP on tumour volumes in DLA-challenged mice.

was found to inhibit the proliferation of rat colonic adenocarcinoma cells and angiogenesis [44]. Zerumbone isolated from the rhizomes of Zingiber zerumbet is one of the most promising chemopreventive agents against colon and skin cancer cells [45] and is shown to induce apoptosis in various tumour cells $[46,47]$. This compound is also found to induce antiproliferative effects in the breast carcinoma cells [48], exerts apoptosis through Caspase 3 activation in He La cells [49], and modulates the Bax/Bcl-2 ratio in liver cancer cells [50].

Various antineoplastic compounds have been isolated from the Curcuma species [20]. Curcumin isolated from Curcuma longa has been shown to suppress the proliferation of a wide variety of tumour cells through downregulation of antiapoptotic gene products, activation of caspases, and induction of tumour suppressor genes such as p53 [5153]. Curdione isolated from Curcuma aromatica, a close relative of Curcuma zedoaria, was found to show inhibitory effects on Caco-2 cells [54]. Furanodiene is one of primary anticancer active components in the essential oil of Curcuma wenyujin, very effective agent against uterine cervix cancer and has protection effect on the immune function [55]. Curcuminoids isolated from C. zedoaria rhizomes were demonstrated to be cytotoxic against human ovarian cancer 
TABLE 4: Effect of the i.p administration of the purified fraction of Curcuma zedoaria on the life span of DLA tumour bearing mice.

\begin{tabular}{|c|c|c|c|c|c|}
\hline \multirow{2}{*}{ Treatments } & \multicolumn{3}{|c|}{ No: of mice survived after tumour inoculation (days) } & \multirow{2}{*}{$\begin{array}{c}\text { Mean } \\
\text { survival time } \\
(\mathrm{MST})(\text { days })\end{array}$} & \multirow{2}{*}{$\begin{array}{l}\text { Increase in } \\
\text { life span }(\%)\end{array}$} \\
\hline & 15 & 25 & 35 & & \\
\hline Group 1 (DLA Control) & $6 / 6$ & $0 / 6$ & $0 / 6$ & $21 \pm 2.1$ & - \\
\hline Group 2 CZPF $62.5 \mathrm{mg} / \mathrm{kg}$ bw & $6 / 6$ & $3 / 6$ & $0 / 6$ & $25 \pm 1.7$ & 19.0 \\
\hline Group 3 CZPF 50 mg/kg bw & $6 / 6$ & $4 / 6$ & $0 / 6$ & $26 \pm 2.0$ & 23.8 \\
\hline Group 4 CZPF $41.6 \mathrm{mg} / \mathrm{kg}$ bw & $6 / 6$ & $4 / 6$ & $0 / 6$ & $29 \pm 2.3$ & 38.0 \\
\hline Group 5 CZPF $35.7 \mathrm{mg} / \mathrm{kg}$ bw & $6 / 6$ & $5 / 6$ & $0 / 6$ & $30 \pm 1.9$ & 42.8 \\
\hline Group 6 CYP (25 mg/kg bw) & $6 / 6$ & $6 / 6$ & $3 / 6$ & $32 \pm 1.5$ & 52.3 \\
\hline
\end{tabular}

OVCAR-3 cells [34]. The antitumor effect of the partially purified polysaccharide from C. zedoaria was studied in mice transplanted with sarcoma 180 cells, and the results suggested that CZ-1-III, the polysaccharide fraction from $C$. zedoaria, decreased the tumor size of mouse and prevented the chromosomal mutation [37]. An essential oil isolated from C. zedoaria was found to possess inhibitory effects against human promyelocytic leukemia HL-60 cells. The GCMS results demonstrated the presence of epicurzerenone and curdione [13]. Our study reports the significant nontoxic nature and antitumour effects of isocurcumenol, a sesquiterpenoid compound isolated from Curcuma zedoaria on the human lung, nasopharyngeal, and leukemic cells as well as the murine lymphoma cells.

Shibuya et al. [56] reported that furanogermenone, curcumenol, and dehydrocurdione were the major oil components of species of C. zedoaria native to China, Taiwan, and Japan [56]. Curzerenone has also been reported as major oil component of the C. zedoaria rhizomes [36, 57-59]. Our studies on the plant rhizomes native to Kerala showed isocurcumenol and methyl sterolate as the major compounds. The present finding could indicate the existence of different chemotypes and regional variation for C. zedoaria.

Earlier reports show that phytochemical investigations carried out in the Curcuma species, namely, Curcuma ochrorhiza and Curcuma heyneana of the Malaysian origin, have resulted in the isolation of six sesquiterpenes including isocurcumenol [60]. Isocurcumenol has already been isolated from Curcuma zedoaria of the Chinese origin $[36,58]$, and we could isolate the same compound from rhizomes of Indian origin too.

The curcuminoids isolated from Curcuma zedoaria were reported to inhibit the growth of ovarian carcinoma (OVCAR-3), leukemic (HL-60), S-180 sarcoma, and mouse cervical U-14 cells $[13,14,34]$. In the present study, among the four cancer cell lines tested, isocurcumenol induced significant antiproliferative effects in the inhibition of proliferation of DLA, A 549, K562, and KB cells.

Intraperitoneal administration of the purified fractions from the plant rhizomes exhibited differential toxicity profile in mice at different doses. The results showed that the animals could tolerate a reasonably high dose of CZ-PF. The treatment of the purified fractions at sublethal doses did not decrease the food and water intake as well as the body weight.
Estimation of the liver function tests of SGOT, SGPT, and ALKP is mostly used for measuring hepatocellular injury. The microscopic analysis of the target organs, liver, spleen and, kidney, did not show significant changes in architecture and texture in animals treated with 1/12th and 1/14th of sublethal doses when compared with the control group. The increase in SGOT and SGPT in serum at very high doses may be due to hepatocellular necrosis, which causes increase in the permeability of the cell membrane resulting in release of transaminases into the blood stream. Also there was not much toxicity in the kidney function tests as reflected from the levels of urea and creatinine at these doses. The normal levels of blood urea and creatinine indicated that the purified fractions at these doses did not interfere with the renal function and the renal integrity was preserved.

The reliable criteria for judging the value of any anticancer drug is prolongation of life span [61]. The purified fraction, CZ-PF, showed profound antitumour effects against DLA cells in mice models as evidenced by the increase in the lifespan and decrease in the ascitic tumour volume. From the results obtained, we can conclude that there was a good response of antitumour activity in in vitro cell culture experiments as well as in vivo antitumour studies. All the animals were apparently healthy indicating no side effects. The cell culture experiments showed remarkable activity in arresting the growth of tumour cell lines of different origin both in crude and purified forms. All these indicated that the plants possess a potential antitumour activity. The good antitumour responses observed were due to the potent sesquiterpenoid compound isocurcumenol isolated from the purified fraction of Curcuma zedoaria. immunomodulation, Immunostimulation, effects on humoral immune response, anti-angioneogenesis activity in addition to cytotoxicity towards the tumour cells might be the probable mechanisms by which the reduction in tumour growth was achieved after treatment with CZ-PF. As CZ-PF is having good safety profile without much of toxic effects, it may be ideal candidate for prospective trials on more tumour cells.

\section{Conclusions}

The compound isolated from the rhizomes of Curcuma zedoaria, characterized as isocurcumenol by the MS and IR spectra significantly inhibited the cell proliferation in human 
lung, leukemia, nasopharyngeal carcinoma and murine lymphoma cells. Acridine orange-Ethidium Bromide and Hoechst staining revealed the apoptosis inducing capacity of isocurcumenol. GC-MS profile of the Petroleum ether extract showed isocurcumenol, methyl sterolate, elemene, and Isolongifolene as the prominent chemical constituents. The in vivo studies suggested the non toxic nature of the compound at low doses and its antitumour effects in the ascitic tumour development comparable to the standard drug used to treat lymphoma, cyclophosphamide. The present study highlights the antitumour potential of isocurcumenol isolated from Curcuma zedoaria to be exploited further to be developed as a good antitumour agent.

\section{Acknowledgment}

The authors gratefully acknowledge Indian Council of Medical Research (ICMR), New Delhi, for the financial support.

\section{References}

[1] B. B. Aggarwal, A. Kumar, and A. C. Bharti, "Anticancer potential of curcumin: preclinical and clinical studies," Anticancer Research, vol. 23, no. 1A, pp. 363-398, 2003.

[2] B. B. Aggarwal and S. Shishodia, "Suppression of the nuclear factor- $\kappa \mathrm{B}$ activation pathway by spice-derived phytochemicals: reasoning for seasoning," Annals of the New York Academy of Sciences, vol. 1030, pp. 434-441, 2004.

[3] B. B. Aggarwal and S. Shishodia, "Molecular targets of dietary agents for prevention and therapy of cancer," Biochemical Pharmacology, vol. 71, no. 10, pp. 1397-1421, 2006.

[4] M. K. Singhal, "Jungles: rich sources of medicinal plants," Natural Product Radiance, vol. 3, p. 203, 2004.

[5] P. K. Lai and J. Roy, "Antimicrobial and chemopreventive properties of herbs and spices," Current Medicinal Chemistry, vol. 11, no. 11, pp. 1451-1460, 2004.

[6] Y. J. Surh, "Molecular mechanisms of chemopreventive effects of selected dietary and medicinal phenolic substances," Mutation Research, vol. 428, no. 1-2, pp. 305-327, 1999.

[7] Y. J. Surh, K. K. Park, K. S. Chun, J. M. Lee, E. Lee, and S. S. Lee, "Anti-tumor- promoting activities of selected pungent phenolic substances present in ginger," Journal of Environmental Pathology, Toxicology and Oncology, vol. 18, no. 2, pp. 131-139, 1999.

[8] Y. J. Surh, "Anti-tumor promoting potential of selected spice ingredients with antioxidative and anti-inflammatory activities: a short review," Food and Chemical Toxicology, vol. 40, no. 8, pp. 1091-1097, 2002.

[9] Y. J. Surh, "Cancer chemoprevention with dietary phytochemicals," Nature Reviews Cancer, vol. 3, no. 10, pp. 768-780, 2003.

[10] Y. J. Surh, E. Lee, and J. M. Lee, "Chemoprotective properties of some pungent ingredients present in red pepper and ginger," Mutation Research, vol. 402, no. 1-2, pp. 259-267, 1998.

[11] N. Chen and S. J. Zhao, "Radioprotection related activities of medicinal plant," Zhongguo Zhongyao Zazhi, vol. 32, no. 13, pp. 1263-1266, 2007.

[12] K. S. Kim, J. M. Paik, and W. I. Hwang, "Determination of antitumor effects of extracts from Korean medicinal plants on cancer cells," Korea University Medical Journal, vol. 25, no. 3, pp. 759-769, 1988.
[13] E. Y. C. Lai, C. C. Chyau, J. L. Mau et al., "Antimicrobial activity and cytotoxicity of the essential oil of Curcuma zedoaria," American Journal of Chinese Medicine, vol. 32, no. 2, pp. 281-290, 2004.

[14] E. J. Lien and W. Li, in Advances in Chinese Medical Materials Research, vol. 5, pp. 433-452, 1985.

[15] C. E. Ficker, M. L. Smith, S. Susiarti, D. J. Leaman, C. Irawati, and J. T. Arnason, "Inhibition of human pathogenic fungi by members of Zingiberaceae used by the Kenyah (Indonesian Borneo)," Journal of Ethnopharmacology, vol. 85, no. 2-3, pp. 289-293, 2003.

[16] S. Z. Li, "Ben-cao gung-mu," in Jiangxi (ed), vol. 2, pp. 880885, The People's Health Pub, House, Beijing, China, 1977.

[17] K. S. Chun, Y. Sohn, H. S. Kim et al., "Anti-tumor promoting potential of naturally occurring diarylheptanoids structurally related to curcumin," Mutation Research, vol. 428, no. 1-2, pp. 49-57, 1999.

[18] M. A. Kuhn and D. Wintston, Herbal Therapy and Supplements: A Scientific and Traditional Approach, Lippincott, New York, NY, USA, 2001.

[19] K. H. Lee, "Antineoplastic compounds and their analogues from Chinese traditional medicine," Journal of the American Chemical Society, vol. 3, pp. 170-190, 1993.

[20] H. W. D. Matthes, B. Luu, and G. Ourisson, "Cytotoxic components of Zingiber zerumbet, Curcuma zedoaria and C. domestica," Phytochemistry, vol. 19, no. 12, pp. 2643-2650, 1980.

[21] M. Nagabhushan and S. V. Bhide, "Curcumin as an inhibitor of cancer," Journal of the American College of Nutrition, vol. 11, no. 2, pp. 192-198, 1992.

[22] R. Lobo, K. S. Prabhu, A. Shirwaikar, and A. Shirwaikar, "Curcuma zedoaria Rosc, (white turmeric): a review of its chemical, pharmacological and ethnomedicinal properties," Journal of Pharmacy and Pharmacology, vol. 61, no. 1, pp. 1321, 2009.

[23] N. Saikia and S. C. Nath, "Ethnobotanical observations of some species of the genus Curcuma L. growing in Assam," Journal of Economic and Taxonomic Botany, vol. 27, pp. 430433, 2003.

[24] M. K. Jang, D. H. Sohn, and J. H. Ryu, "A curcuminoid and sesquiterpenes as inhibitors of macrophage TNF- $\alpha$ release from Curcuma zedoaria," Planta Medica, vol. 67, no. 6, pp. 550-552, 2001.

[25] T. Yoshioka, E. Fujii, M. Endo et al., "Antiinflammatory potencg of dehydrocurdione, a zedoary-derived sesquiterpene," Inflammation Research, vol. 47, no. 12, pp. 476-481, 1998.

[26] S. K. Gupta, A. B. Banerjee, and B. Achari, "Isolation of ethyl p-methoxycinnamate, the major antifungal principle of Curcuma zedoaria," Lloydia, vol. 39, no. 4, pp. 218-222, 1976.

[27] K. Watanabe, M. Shibata, and S. Yano, "Antiulcer activity of extracts and isolated compounds from Zedoary (Gajutsu) cultivated in Yakushima (Japan)," Yakugaku Zasshi, vol. 106, no. 12, pp. 1137-1142, 1986.

[28] B. Wilson, G. Abraham, V. S. Manju et al., "Antimicrobial activity of Curcuma zedoaria and Curcuma malabarica tubers," Journal of Ethnopharmacology, vol. 99, no. 1, pp. 147-151, 2005.

[29] A. Bugno, M. Aparecida, N. Adriana et al., "Antimicrobial efficacy of Curcuma zedoaria extract as assessed by linear regression compared with commercial mouthrinses," Brazilian Journal of Microbiology, vol. 38, pp. 1517-8382, 2007. 
[30] H. Matsuda, K. Ninomiya, T. Morikawa, and M. Yoshikawa, "Inhibitory effect and action mechanism of sesquiterpenes from zedoariae rhizoma on D-galactosamine/ lipopolysaccharide-induced liver injury," Bioorganic and Medicinal Chemistry Letters, vol. 8, no. 4, pp. 339-344, 1998.

[31] A. C. Rana and Y. Avadhoot, "Experimental evaluation of hepatoprotective activity of Gymnema sylvestre and Curcuma zedoaria," Fitoterapia, vol. 63, no. 1, pp. 60-62, 1992.

[32] M. H. Ansari and S. Ahmad, "Curcuma zedoaria root extract: in vitro demonstration of antiamoebic activity," Biomedical Research, vol. 2, no. 2, pp. 192-196, 1991.

[33] O. J. Oh, H. Y. Min, and S. K. Lee, "Inhibition of inducible prostaglandin E2 production and cyclooxy-genase-2 expression by curdione from Curcuma zedoaria," Archives of Pharmacal Research, vol. 30, no. 10, pp. 1226-1239, 2007.

[34] W. J. Syu, C. C. Shen, M. J. Don, J. C. Ou, G. H. Lee, and C. M. Sun, "Cytotoxicity of curcuminoids and some novel compounds from Curcuma zedoaria," Journal of Natural Products, vol. 61, no. 12, pp. 1531-1534, 1998.

[35] H. H. Chae, S. N. Min, Y. L. Woo, and K. L. Sang, "Inhibitory effects of natural sesquiterpenoids isolated from the rhizomes of Curcuma zedoaria on prostaglandin $\mathrm{E}$ and nitric oxide production," Planta Medica, vol. 68, no. 6, pp. 545-547, 2002.

[36] Y. Shiobara, Y. Asakawa, M. Kodama, K. Yasuda, and T. Takemoto, "Curcumenone, curcumanolide A and curcumanolide B, three sesquiterpenoids from Curcuma zedoaria," Phytochemistry, vol. 24, no. 11, pp. 2629-2633, 1985.

[37] K. I. Kim, J. W. Kim, B. S. Hong et al., "Antitumor, genotoxicity and anticlastogenic activities of polysaccharide from Curcuma zedoaria," Molecules and Cells, vol. 10, no. 4, pp. 392-398, 2000.

[38] K. I. Kim, K. S. Shin, W. J. Jun et al., "Effects of polysaccharides from rhizomes of Curcuma zedoaria on macrophage functions," Bioscience, Biotechnology and Biochemistry, vol. 65, no. 11, pp. 2369-2377, 2001.

[39] C. B. Lim, N. Ky, H. M. Ng, M. S. Hamza, and Y. Zhao, "Curcuma wenyujin extract induces apoptosis and inhibits proliferation of human cervical cancer cells in vitro and in vivo," Integrative cancer therapies, vol. 9, no. 1, pp. 36-49, 2010.

[40] D. A. Scudiero, R. H. Shoemaker, K. D. Paull et al., "Evaluation of a soluble tetrazolium/formazan assay for cell growth and drug sensitivity in culture using human and other tumor cell lines," Cancer Research, vol. 48, no. 17, pp. 4827-4833, 1988.

[41] M. Kirsh Volders, A. Elhajouji, E. Cundari, and P. Van Hummelen, "The invitro micronuclear test: a multi-endpoint assay to detect simultaneous mitotic delay, apoptosis, chromosome breakage and non-disjunction," Mutation Research, vol. 436, pp. 69-97, 1997.

[42] M. I. Pörn-Ares, S. C. Chow, J. P. Slotte, and S. Orrenius, "Induction of apoptosis and potentiation of TNF- and FAS-mediated apoptosis in U937 cells by the xanthogenate compound D609," Experimental Cell Research, vol. 235, no. 1, pp. 48-54, 1997.

[43] P. C. Vincent and A. Nicholls, "Comparison of the growth of the Ehrlich ascites tumor in male and female mice," Cancer Research, vol. 27, no. 6, pp. 1058-1065, 1967.

[44] A. C. Brown, C. Shah, J. Liu, J. T. H. Pham, G. Z. Jian, and M. R. Jadus, "Ginger's (Zingiber officinale Roscoe) inhibition of rat colonic adenocarcinoma cells proliferation and angiogenesis in vitro," Phytotherapy Research, vol. 23, no. 5, pp. 640-645, 2009.

[45] Y. Nakamura, C. Yoshida, A. Murakami, H. Ohigashi, T. Osawa, and K. Uchida, "Zerumbone, a tropical ginger sesquiterpene, activates phase II drug metabolizing enzymes," FEBS Letters, vol. 572, no. 1-3, pp. 245-250, 2004.

[46] A. Murakami, D. Takahashi, T. Kinoshita et al., "Zerumbone, a Southeast Asian ginger sesquiterpene, markedly suppresses free radical generation, proinflammatory protein production, and cancer cell proliferation accompanied by apoptosis: the $\alpha, \beta$-unsaturated carbonyl group is a prerequisite," Carcinogenesis, vol. 23, no. 5, pp. 795-802, 2002.

[47] B. Sung, A. Murakami, B. O. Oyajobi, and B. B. Aggarwal, "Zerumbone abolishes RaNKL-induced NF- $\kappa$ B activation, inhibits osteoclastogenesis, and suppresses human breast cancer-induced bone loss in athymic nude mice," Cancer Research, vol. 69, no. 4, pp. 1477-1484, 2009.

[48] R. A. Rashid and A. H. L. Pihie, "The antiproliferative effects of Zingiber zerumbet extracts and fractions on the growth of human breast carcinoma cell lines," Malaysian Journal of Pharmaceutical sciences, vol. 3, pp. 45-52, 2005.

[49] A. B. H. Adbul, A. S. Al-Zubairi, N. D. Tailan et al., "Anticancer activity of natural compound (Zerumbone) extracted from Zingiber zerumbet in human HeLa cervical cancer cells," International Journal of Pharmacology, vol. 4, no. 3, pp. 160$168,2008$.

[50] S. A. Sharifah Sakinah, S. Tri Handayani, and L. P. Azimahtol Hawariah, "Zerumbone induced apoptosis in liver cancer cells via modulation of Bax/Bcl-2 ratio," Cancer Cell International, vol. 7, article 4, 2007.

[51] S. Aggarwal, H. Ichikawa, Y. Takada, S. K. Sandur, S. Shishodia, and B. B. Aggarwal, "Curcumin (diferuloylmethane) downregulates expression of cell proliferation and antiapoptotic and metastatic gene products through suppression of $\mathrm{I} \kappa \mathrm{B} \alpha$ kinase and Akt activation," Molecular Pharmacology, vol. 69, no. 1, pp. 195-206, 2006.

[52] R. J. Anto, A. Mukhopadhyay, K. Denning, and B. B. Aggarwal, "Curcumin (diferuloylmethane) induces apoptosis through activation of caspase-8, BID cleavage and cytochrome c release: its suppression by ectopic expression of Bcl-2 and Bclxl," Carcinogenesis, vol. 23, no. 1, pp. 143-150, 2002.

[53] R. J. Anto, T. T. Maliekal, and D. Karunagaran, "L-929 cells harboring ectopically expressed RelA resist curcumin-induced apoptosis," Journal of Biological Chemistry, vol. 275, no. 21, pp. 15601-15604, 2000.

[54] X.-L. Hou, K. Takahashi, N. Kinoshita et al., "Possible inhibitory mechanism of Curcuma drugs on CYP3A4 in $1 \alpha, 25$ dihydroxyvitamin $\mathrm{D}_{3}$ treated Caco- 2 cells," International Journal of Pharmaceutics, vol. 337, no. 1-2, pp. 169-177, 2007.

[55] Z. Z. Ba, Y. P. Zheng, H. Zhang, X. Y. Sun, and D. H. Lin, "Potential anti-cancer activity of furanodiene," Chinese Journal of Cancer Research, vol. 21, no. 2, pp. 154-158, 2009.

[56] H. Shibuya, Y. Minoru, K. Eisaku, N. Masakazu, and K. Isao, "Qualitative and quantitative analysis of essential oil constituents in various Zedoariae Rhizoma (Gajutsu) by gas liquid chromatography-mass spectrometry," Yakugaku Zasshi, vol. 106, pp. 212-216, 1986.

[57] F. Seigo, K. Masanori, U. Akira, A. Yukio, and S. Yasuhisa, "Structure of curzerenone, a new sesquiterpene from Curcuma zedoaria," Yakugaku Zasshi, vol. 90, pp. 863-869, 1970.

[58] H. Hikino, K. Agatsuma, and T. Takemoto, "Structure of curzerenone, epicurzerenone, and isofuranogermacrene (curzerene)," Tetrahedron Letters, vol. 9, no. 24, pp. 2855-2858, 1968.

[59] J. Purkayastha, S. C. Nath, and N. Klinkby, "Essential oil of the rhizome of Curcuma zedoaria (Christm.) rosc. Native to northeast India," Journal of Essential Oil Research, vol. 18, no. 2, pp. 154-155, 2006. 
[60] M. Aspollah Sukari, T. S. Wah, S. M. Saad et al., "Bioactive sesquiterpenes from Curcuma ochrorhiza and Curcuma heyneana," Natural Product Research, vol. 24, no. 9, pp. 838845, 2010.

[61] B. D. Clarkson and J. H. Burchenal, "Prelimanary screening of antineoplastic drugs," Progress in Clinical Cancer, vol. 1, p. 625, 1965. 


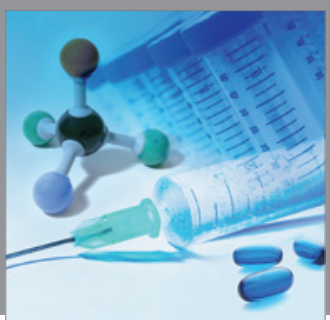

International Journal of

Medicinal Chemistry

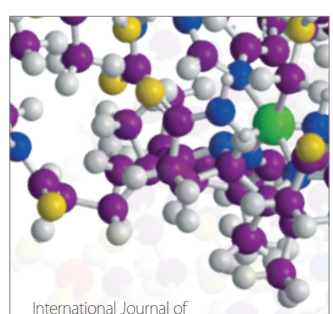

Carbohydrate Chemistry

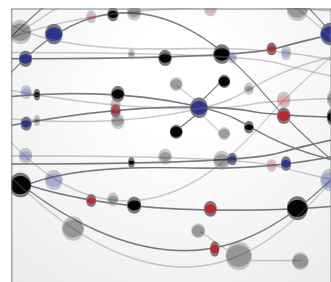

The Scientific World Journal
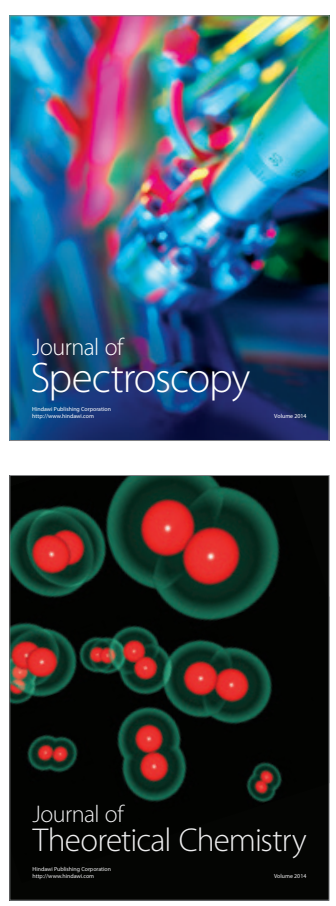
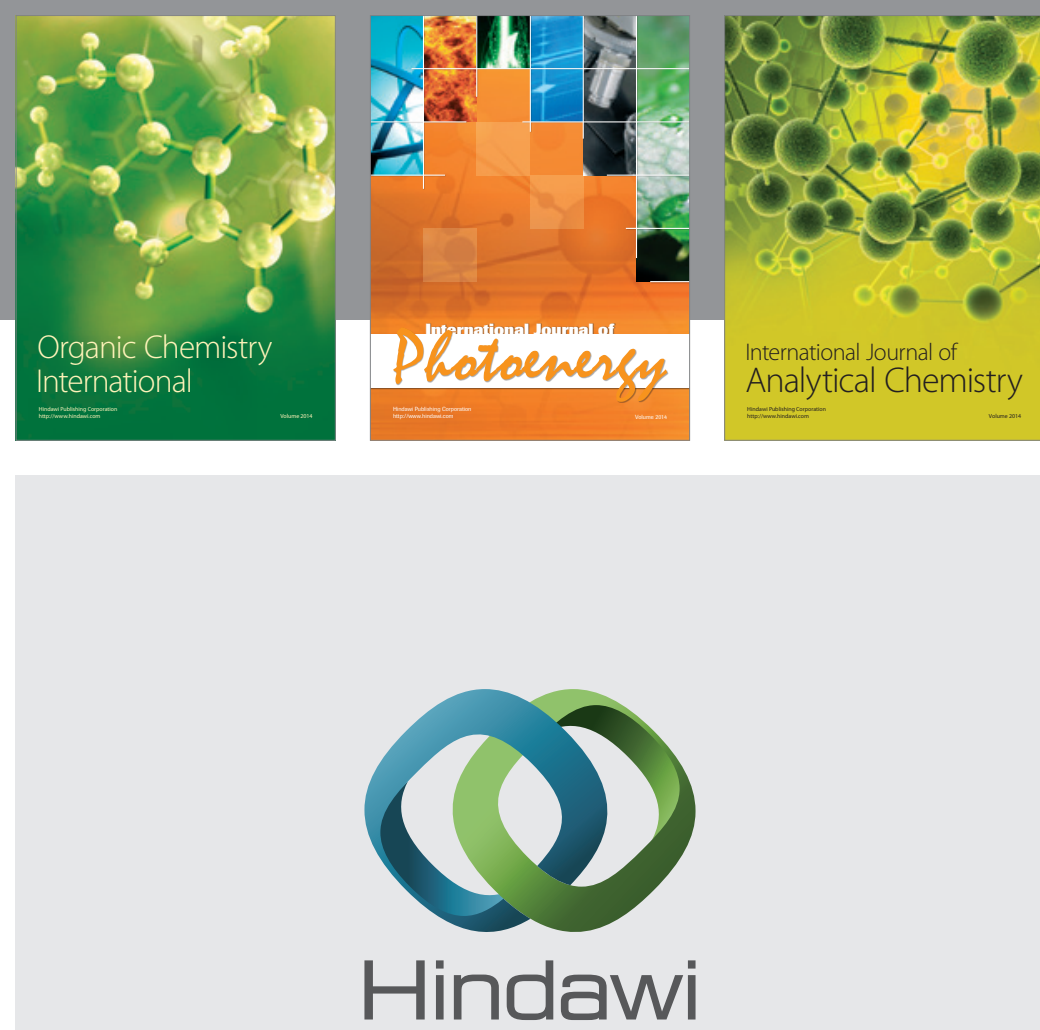

Submit your manuscripts at

http://www.hindawi.com
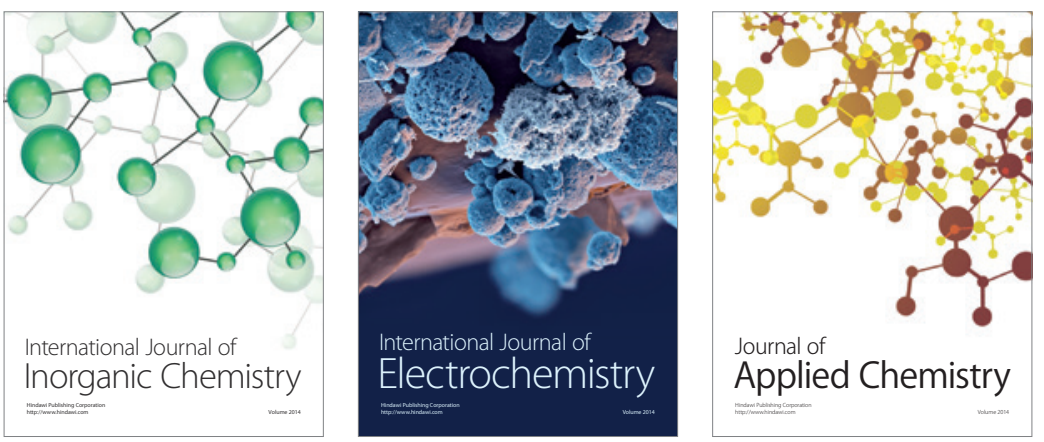

Journal of

Applied Chemistry
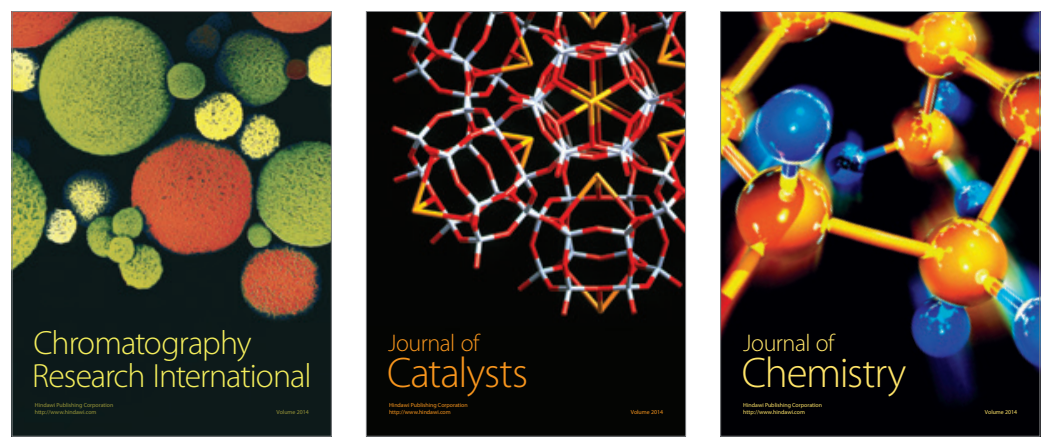
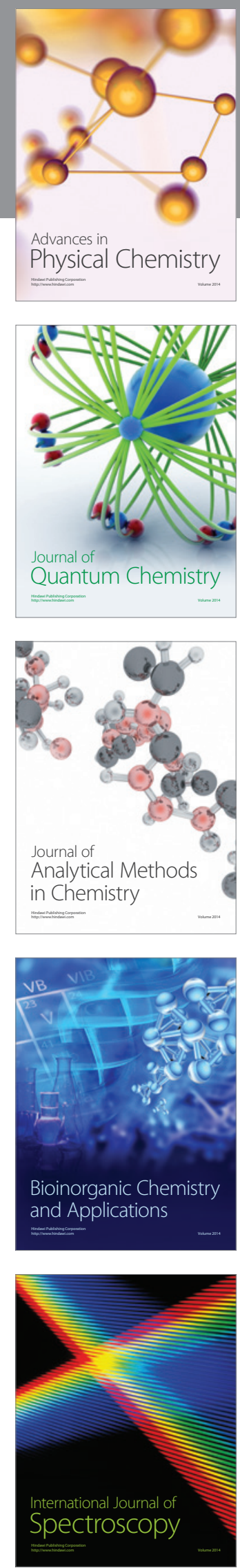